\title{
Defoliation and Soil Compaction Jointly Drive Large-Herbivore Grazing Effects on Plants and Soil Arthropods on Clay Soil
}

\author{
R. van Klink, ${ }^{1 *}$ M. Schrama, ${ }^{2,3}$ S. Nolte, ${ }^{1,4}$ J. P. Bakker, ${ }^{1}$ \\ M. F. WallisDeVries, ${ }^{5,6}$ and M. P. Berg ${ }^{1,7}$
}

\begin{abstract}
${ }^{1}$ Community and Conservation Ecology Group, Centre for Ecological and Evolutionary Studies, University of Groningen, Nijenborgh 7 , 9747 AG Groningen, The Netherlands; ${ }^{2}$ Department of Terrestrial Ecology, Netherlands Institute of Ecology, Droevendaalsesteeg 10, 6708 PB Wageningen, The Netherlands; ${ }^{3}$ Faculty of Life Sciences, University of Manchester, Oxford Road, Michael Smith Building, Manchester M13 9PT, UK; ${ }^{4}$ Present address: Applied Plant Ecology, University of Hamburg, Ohnhorststr. 18, 22609 Hamburg, Germany; ${ }^{5}$ De Vlinderstichting/Dutch Butterfly Conservation, P.O.Box 506, 6700 AM Wageningen, The Netherlands; ${ }^{6}$ Laboratory of Entomology, Wageningen University, P.O.Box 8031, 6700 EH Wageningen, The Netherlands; ${ }^{7}$ Department of Ecological Science Section Animal Ecology, VU University, De Boelelaan 1085, 1081 HV Amsterdam, The Netherlands
\end{abstract}

\begin{abstract}
In addition to the well-studied impacts of defecation and defoliation, large herbivores also affect plant and arthropod communities through trampling, and the associated soil compaction. Soil compaction can be expected to be particularly important on wet, fine-textured soils. Therefore, we established a full factorial experiment of defoliation (monthly mowing) and soil compaction (using a rammer, annually) on a clay-rich salt marsh at the Dutch coast, aiming to disentangle the importance of these two factors. Additionally, we compared the effects on soil physical properties, plants, and arthropods to those at a nearby cattle-grazed marsh under dry and
\end{abstract}

Received 4 August 2014; accepted 18 January 2015

published online 10 March 2015

Electronic supplementary material: The online version of this article (doi:10.1007/s10021-015-9855-z) contains supplementary material, which is available to authorized users.

Author contributions RvK, MS, JPB Conceived and designed the study. RvK, MS, SN Performed the research. RvK, MS, MPB Analyzed the data. RvK, MS, JPB, MFW, MPB Wrote the paper.

R. van Klink and M. Schrama have contributed equally to this work.

*Corresponding author; e-mail: r.van.klink@rug.nl under waterlogged conditions. Soil physical conditions of the compacted plots were similar to the conditions at cattle-grazed plots, showing decreased soil aeration and increased waterlogging. Soil salinity was doubled by defoliation and quadrupled by combined defoliation and compaction. Cover of the dominant tall grass Elytrigia atherica was decreased by $80 \%$ in the defoliated plots, but cover of halophytes only increased under combined defoliation and compaction. Effects on soil microarthropods were most severe under waterlogging, showing a fourfold decrease in abundance and a smaller mean body size under compaction. Although the combined treatment of defoliation and trampling indeed proved most similar to the grazed marsh, large discrepancies remained for both plant and soil fauna communities, presumably because of colonization time lags. We conclude that soil compaction and defoliation differently affect plant and arthropod communities in grazed ecosystems, and that the magnitude of their effects depends on herbivore density, productivity, and soil physical properties.

Key words: Collembola; Acari; Aranaea; Coleoptera; macro-detritivores; simulated grazing. 


\section{INTRODUCTION}

Large herbivores exert strong impacts on their habitat and other species (Trimble and Mendel 1995; Hobbs 2006). Traditionally, defoliation and defecation have been viewed as the most important mechanisms by which herbivores affect their environment (for example, McNaughton and others 1997; Borer and others 2014), but recently effects of trampling have received increasing attention. Trampling may provide a complementary explanation for the grazing response of plants (Sørensen and others 2009) and soil fauna (Cole and others 2008; Sørensen and others 2009; Schon and others 2010), as well as for belowground processes, such as nutrient mineralization rates (Schrama and others 2013a, b).

Trampling can not only directly kill or damage plants or animals, but also cause soil compaction through the application of pressure on the soil surface. From agricultural literature, it is known that soil compaction decreases pore space and connectivity, and hence transport of oxygen and water (Horn and others 1995; Hamza and Anderson 2005; Cole and others 2008). This can be detrimental to plant productivity (for example, Lipiec and others 1991), soil fauna abundance (Aritajat and others 1977; Heisler 1994; Beylich and others 2010), and nutrient cycling (Breland and Hansen 1996; Rasiah and Kay 1998). The consequences of soil compaction due to trampling for plant and animal communities in low-intensity animal husbandry and naturally grazed ecosystems are, however, poorly known and are difficult to separate from the effects of defoliation, as the two are usually spatially correlated. It has been hypothesized that soil compaction is particularly important in fine-textured clay soils, where under wet conditions decreased pore connectivity leads to increased waterlogging and anoxic conditions (Liddle 1997; Schrama and others 2013b).

The effects of defoliation by large herbivores usually differ from those of trampling. Although variable effects have been reported, recent syntheses show that defoliation is generally positive for plant species richness (Borer and others 2014) due to a reduction in light competition, but often negative for species richness of aboveground arthropods (Van Klink and others, in press) due to a decrease in plant biomass and structural vegetation complexity. Indirectly, also belowground fauna can be affected by defoliation, foremost by an increase in soluble carbon from increased root exudation (Holland and others 1996; Hamilton and Frank 2001; Bardgett and Wardle 2003).
With respect to the relative impact of trampling and defoliation on plant and animal communities, contrasting results have been reported from different ecosystems. In alpine grasslands, weak effects of both defoliation and trampling were found on plant and microbial communities (Kohler and others 2004, 2005). Similarly, in Mediterranean grasslands, no differences between the effects of trampling and defoliation were observed (Dobarro and others 2013). In these ecosystems, the physical damage to plants caused by trampling is obviously severe, but soil compaction is unlikely to be important on these welldrained, coarse-textured soils (Schrama and others 2013b; Veldhuis and others 2014). By contrast, on an organic, wet soil in the subarctic tundra, physical damage by trampling was the most important factor increasing plant species richness (Olofsson and Shams 2007) and decreasing decomposer abundances (Sørensen and others 2009). Although effects of compaction can be expected to be most pronounced on poorly drained clay soils, an experimental approach separating the relative contributions of defoliation and compaction has so far been lacking.

Western European coastal salt marshes are grasslands that are regularly flooded by sea water. They typically occur on poorly drained, clay-rich soils and are often used for livestock grazing. Soil oxygen availability (redox potential) and salinity are the most important abiotic determinants for plant species occurrence in this habitat (Davy and others 2011) and can both be modified by livestock grazing (Esselink and others 2000; Schrama and others 2013a). Here, we report results of a full factorial experiment of defoliation and soil compaction on a temperate salt marsh. We compared communities of plants, epigeic fauna, and soil micro-arthropods between treatments and to those of a nearby cattle-grazed salt marsh. The soil conditions on these marshes undergo strong seasonal fluctuations with dry conditions prevailing in summer and waterlogging in autumn; therefore, we took measurements under both conditions (June and September).

Starting from a long-term ungrazed situation, dominated by the tall grass Elytrigia atherica, we expected that grazed conditions overall would best be approximated by the combined effects of defoliation and soil compaction. With respect to the different biotic groups in our study, we expected the relative importance of the effects of the two factors to differ. Specifically, we expected plant community composition to be explained by both defoliation and soil compaction because plants lose aboveground biomass to defoliation whereas the 
roots are affected by soil compaction. Because compaction reduces soil aeration, we expected the halophytic species, adapted to anoxic conditions, to increase in cover in the compacted soil, at the expense of glycophytes. The abundance and species richness of epigeic fauna (arthropods living on the soil surface) were expected to be mostly affected by defoliation because this directly reduces vegetation structural complexity and litter accumulation. Finally, we expected abundance and species richness of soil micro-arthropods to be mostly negatively affected by soil compaction, where especially the larger species are expected to be excluded or reduced in abundance due to reduced pore space and pore accessibility due to water logging.

\section{Materials AND Methods}

\section{Study Site}

The study was conducted on a salt marsh at the Dutch Wadden sea coast (Noord Friesland Buitendijks, $53^{\circ} 20^{\prime} \mathrm{N} ; 05^{\circ} 43^{\prime} \mathrm{E}$ ). Our study site is a typical mainland salt marsh with a soil consisting of several meters of marine clay deposits.

Livestock grazing has been a common practice on western European salt marshes for centuries (Bazelmans and others 2012). At our study site, grazing leads to a complex matrix of several shortstatured grass and forb species (in the order of dominance: Agrostis stolonifera, Plantago maritima, Puccinellia maritima, Glaux maritima). In the absence of grazing, the tall grass $E$. atherica dominates interspersed with patches of $A$. stolonifera, Aster tripolium and the annual forb Atriplex prostrata.

Our experimental plots were located in a longterm ungrazed ( $>25$ years) salt marsh, at a standardized elevation of about $45 \mathrm{~cm}$ above mean high tide (MHT). Average inundation frequency at this elevation was 35 inundations year ${ }^{-1}$ over 2008-2010 (Data Rijkswaterstaat). The soil is waterlogged during at least 7 months a year, (from late August until early April), depending on precipitation, inundations, and evapotranspiration.

\section{Experimental Design}

For our full factorial experiment, we chose eight replicate patches (diameter about $6 \mathrm{~m}$ ) with $100 \%$ cover of E. atherica. Each of these patches was subdivided into four $1.5-2.0 \mathrm{~m}^{2}$ plots, leaving where possible more than $50 \mathrm{~cm}$ of untreated vegetation between all plots. Each plot was randomly assigned to one of the four treatments: control, defoliation (D), soil compaction (C), and defoliation and soil compaction $(\mathrm{D}+\mathrm{C})$. Root and stolon connections of E. atherica were severed along the edge of each experimental plot to $20-\mathrm{cm}$ depth at the start of the experiment, using a knife.

Preceding the first compaction round, defoliation was performed by mowing the vegetation down to 5 -cm height using a brush cutter, in September 2010. Thereafter, mowing was carried out by manually clipping to $5 \mathrm{~cm}$ above the soil surface at monthly intervals during the growing seasons (June-September) of 2011 and 2012. Clipped biomass was removed from the plots by hand.

Compaction was performed using a rammer (Bomag BT60/4; $62 \mathrm{~kg}$, surface $784 \mathrm{~cm}^{2}, 13.5 \mathrm{kN}$, $704 \mathrm{bpm})$. We walked the rammer three times over the plots at the regular speed of the machine. The total pressure applied to the soil was comparable to $30-50$ hoof treads, given a hoof pressure of $220 \mathrm{kPa}$ (Di and others 2001) and a forward momentum of $2 \mathrm{~cm}$ beat $^{-1}$. Soil compaction was carried out in October 2010 (wet soil), and thereafter in June 2011 and June 2012 (dry soil) to compact freshly deposited sediment from winter inundations.

To compare our treatments to the grazed situation, we chose eight replicate plots, spaced $10 \mathrm{~m}$ apart in a grazed salt marsh (stocking density 1 cow $\mathrm{ha}^{-1}$, grazed May to October). This grazing regime has been fairly stable for at least 10 years, although the site was grazed at unknown densities for decades. These plots were located approximately $1 \mathrm{~km}$ from the experimental plots, at the same elevation above MHT and had a soil texture comparable to the experimental plots (Nolte and others 2013).

\section{Sampling}

\section{Soil Physical Properties}

To test the effect of our experimental treatments, we assessed a number of soil physical parameters. We measured bulk density, air-filled porosity, and soil moisture content in June 2011 (7 months after the first compaction round), when the soil was relatively dry, and in September 2011 (4 months after the second compaction round) when the soil was waterlogged, and measured soil salt concentration in August 2011. For details on the methodology, see Online Appendix A.

We measured soil redox potential, as a proxy for oxygen availability, in the field, using a Graphtec GL200 data logger with five Pt electrodes and an $\mathrm{HgCl}$ reference electrode following Schrama and others (2013a) at 2-, 5- and 10-cm depth in all plots on September 27th, 2011. Low redox potential is associated with low oxygen availability and the production of toxic compounds, such as $\mathrm{H}_{2} \mathrm{~S}$ and reduced metals (Laanbroek 1990). 


\section{Plants}

We estimated the cover percentage of each plant species in all plots twice yearly (June and September), from September 2010 until September 2012.

Nomenclature follows Van der Meijden (2005). To assess the effect of compaction on survival of the roots of E. atherica, we calculated the proportion of living and dead roots and rhizome biomass. For details, see Online Appendix A.

\section{Fauna}

We sampled macro-fauna in late September 2011 , using one pitfall trap $(\varnothing 10 \mathrm{~cm})$ per plot surrounded by $50 \mathrm{~cm} \times 50 \mathrm{~cm}$ Perspex enclosures for 1 week. We counted the individuals of the crustacean macro-detritivore Orchestia gammarellus and identified all spiders and beetles to species level using Roberts (1995) and Freude and others (19651999), respectively.

We collected soil micro-arthropods (Collembola and Acari) in June (dry soil) and September (waterlogged soil) 2011 by taking soil cores $(\varnothing 10 \mathrm{~cm}$, $10 \mathrm{~cm}$ depth) from the center of each of the plots and divided these into the upper $(0-5 \mathrm{~cm})$ and lower $(5-10 \mathrm{~cm})$ strata. Soil fauna were extracted in a Tullgren-type extractor (Van Straalen and Rijninks 1982), stored in an ethanol-formaldehyde solution, and identified to species level using Fjellberg $(1998,2007)$ for Collembola, Weigman (2006) for oribatid mites, and Karg (1993) for mesostigmatid mites. Astigmata and Prostigmata were identified to family or genus level using Hughes (1976) and Krantz and Walter (2009), and subsequently sorted over morpho-species. From the sampling in June, we identified fauna from four randomly chosen replicates due to the vast numbers of individuals, and from the sampling in September we identified all fauna from all plots.

Data on average body length were collected from the literature for Acari (Karg 1993; Weigmann 2006) and Collembola (Fjellberg 1998, 2007). For the morpho-species of the Astigmata and the Prostigmata, we performed measurements of body length ourselves (for details see Online Appendix A and Table Al).

\section{Statistical Analyses}

We used a series of univariate and multivariate models with backward model selection to analyze the effects of our treatments on soil properties, plants, and arthropods. An overview of the models used for each group of organisms is given in
Table 1, and a detailed account of the analyses can be found in Online Appendix A. In general, models comparing the compaction and defoliation effects followed a simple compaction $(\mathrm{y} / \mathrm{n}) *$ defoliation $(\mathrm{y} / \mathrm{n})$ design. In models comparing the treated plots to the grazed conditions, all five treatments were entered as separate levels, where 'grazed' was re-leveled as null treatment. Models that showed overdispersion of the residuals (common for Poisson and binomial models) were corrected using individual-level random effects (Online Appendix A; Table 1). All statistical analyses were done in $\mathrm{R}$ version 3.1.1 (R Core Team 2014).

For each group of organisms (plants, epigeic fauna, and soil micro-arthropods at $0-5 \mathrm{~cm}$ depth and $5-10 \mathrm{~cm}$ depth), we assessed the effects of defoliation and soil compaction on community composition using permutational multivariate analysis of variance (MANOVA; "adonis" in the Vegan R library; Oksanen and others 2014). As factorial explanatory variables, we used defoliation, soil compaction, and their interaction. Significance was assessed by 10,000 permutations of the raw data, but to account for our nested design, permutations were only allowed within replicates. These analyses were visualized using non-metric multidimensional scaling (NMDS) of Bray-Curtis dissimilarities.

We tested for the effects of defoliation and soil compaction on soil properties (soil bulk density, soil moisture content, air-filled porosity, salt concentration, and redox potential) using generalized linear mixed models [GLMM; lme4 library (Bates and others 2014)], where replicate was included as random factor. Because lme 4 does not provide $P$ values for normally distributed models, we obtained these using the lmerTest library (Kuznetsova and others 2014), where degrees of freedom are calculated by Satterthwaite's approximation.

Changes in the plant community were assessed by comparing cover of the tall grass $E$. atherica, the combined cover percentage of three short-statured grass species dominant on grazed salt marshes $(A$. stolonifera, Festuca rubra and Pu. maritima), and cover of halophytes and glycophytes using GLMM with binomial distributions (Table 1). Classification of halophytes and glycophytes was done conservatively, and only species restricted to the lower salt marsh according to Van der Meijden (2005) were classified as halophytes: Pu. maritima, Suaeda maritima, and Salicornia europaea. As glycophytes we classified only those species that are not restricted to salt marshes: F. rubra, A. stolonifera, Polygonum aviculare and Tripleurospermum maritimum. Species occurring along the entire salt marsh 
Table 1. Summarized Univariate and Multivariate Models Testing the Effects of Defoliation and Soil Compaction on Different Soil Parameters and Biotic Groups

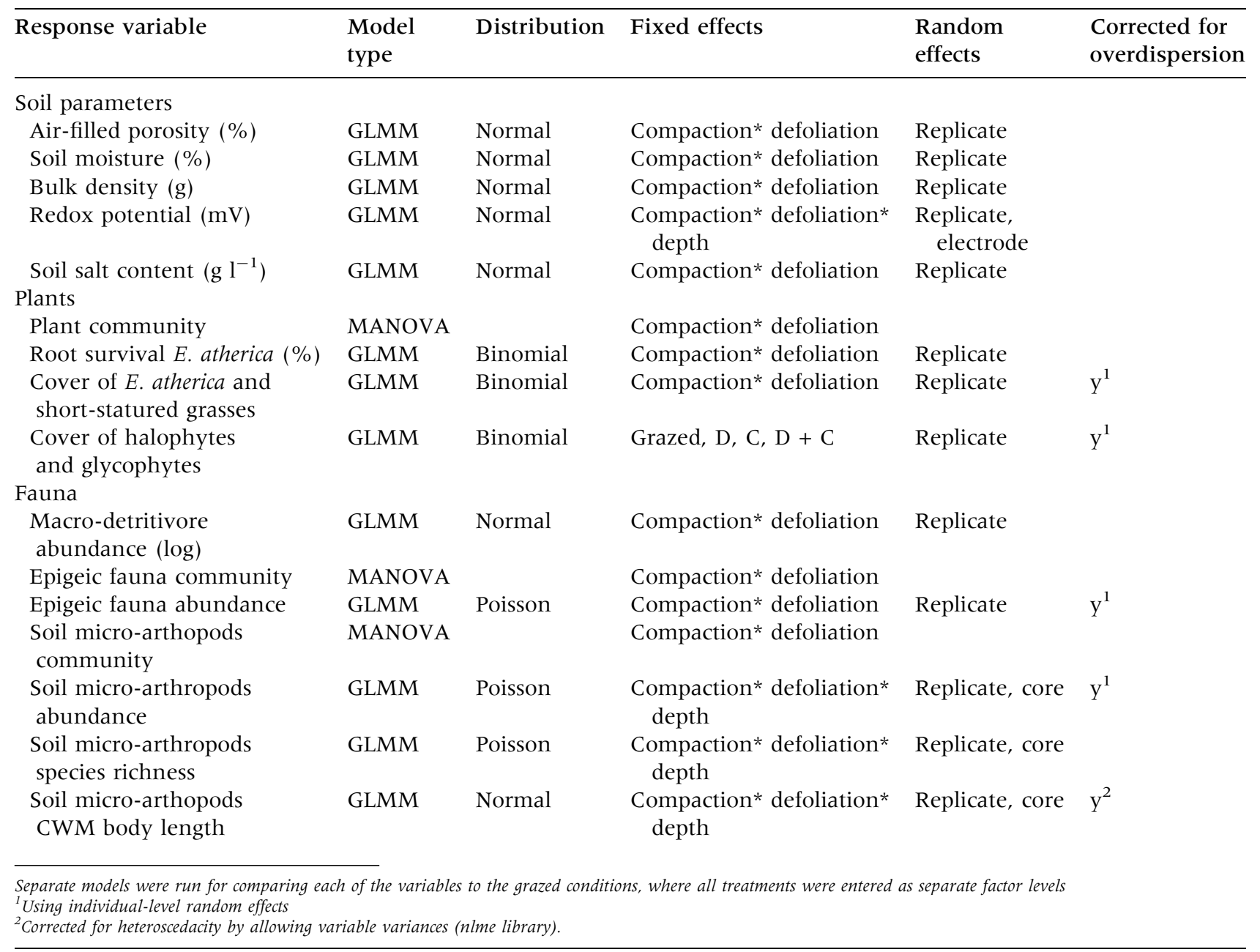

gradient, such as A. tripolium, G. maritima, A. prostrata, and $P l$. maritima, or occurring only at higher elevations such as E. atherica were unclassifiable and, hence, excluded from this analysis. One grazed plot with an exceptionally high cover of the halophytic grass $P u$. maritima $(70 \%)$ was excluded from the analysis of halophyte and glycophyte cover.

Abundance of macro-detritivores, epigeic fauna, and soil micro-arthropods and species richness of soil micro-arthropods were tested for treatment effects using GLMMs (Table 1). Effects of our treatments on the average body size of the soil fauna community were compared for the community-weighted mean (CWM) body length (Garnier and others 2004) of Collembola and Acari. CWM body length was calculated by multiplying the relative abundance of each species with its average adult body length and taking the sum of all species per sample. Because of heteroscedasticity in the variance of CWM body length between treatments, we used the nlme library (Pinheiro and others 2014) to include both a varying variance structure and the nested design.

\section{Results}

\section{Soil Physical Properties}

Air-filled porosity was significantly decreased by both defoliation and compaction, both under dry conditions (June) and under waterlogged conditions (September) (Table 2, Figure la, d). In September, air-filled porosity in the C and D + C plots was equal to that under cattle-grazed conditions (Figure $1 \mathrm{~d}, \quad \mathrm{C}: t=1.36, \quad P=0.18 ; \quad \mathrm{D}+\mathrm{C}$ : $t=0.5, P=0.62)$, but was three times higher in June (Figure la). Soil moisture content was higher 
Table 2. Effects of Defoliation and Soil Compaction on Univariate Parameters, Referring to the Models as Described in Table 1

\begin{tabular}{|c|c|c|c|c|c|c|c|c|}
\hline & \multicolumn{2}{|c|}{ Defoliation } & \multicolumn{2}{|c|}{ Compaction } & \multicolumn{2}{|c|}{$\begin{array}{l}\text { Defoliation* } \\
\text { compaction }\end{array}$} & \multicolumn{2}{|l|}{ Model } \\
\hline & Test stat & $P$ & Test stat & $P$ & Test stat & $P$ & $\chi^{2}$ & $P$ \\
\hline \multicolumn{9}{|l|}{ Soil parameters } \\
\hline Air-filled porosity (\%) June & $t=-2.67$ & $<\mathbf{0 . 0 1}$ & $t=-7.58$ & $<\mathbf{0 . 0 0 1}$ & $t=2.19$ & 0.03 & 54.28 & $<\mathbf{0 . 0 0 1}$ \\
\hline Air-filled porosity (\%) September & $t=-2.33$ & 0.03 & $t=-5.23$ & $<\mathbf{0 . 0 0 1}$ & & & 23.15 & $<0.001$ \\
\hline Soil moisture (\%) June & & & $t=8.76$ & $<\mathbf{0 . 0 0 1}$ & & 0.07 & 49.87 & $<0.001$ \\
\hline Soil moisture (\%) September & & & $t=3.88$ & $<\mathbf{0 . 0 0 1}$ & & & 12.1 & $<0.001$ \\
\hline Bulk density (g) June & $t=2.34$ & 0.02 & & & & & 5.32 & 0.02 \\
\hline Bulk density (g) September & $t=2.64$ & 0.02 & $t=2.72$ & 0.01 & & & 12.07 & $<0.01$ \\
\hline Soil salt concentration & $t=4.24$ & 0.001 & $t=4.51$ & $<\mathbf{0 . 0 0 1}$ & & & 22.76 & $<0.001$ \\
\hline Redox potential $(\mathrm{mV}) 2 \mathrm{~cm}$ & $t=-2.04$ & 0.04 & $t=-9.22$ & $<\mathbf{0 . 0 0 1}$ & $t=-2.04$ & 0.04 & 151.09 & $<\mathbf{0 . 0 0 1}$ \\
\hline Redox potential $(\mathrm{mV}) 5 \mathrm{~cm}$ & $t=-4.05$ & $<0.001$ & $t=-22.69$ & $<\mathbf{0 . 0 0 1}$ & & & 230.55 & $<0.001$ \\
\hline Redox potential $(\mathrm{mV}) 10 \mathrm{~cm}$ & $t=-3.05$ & $<\mathbf{0 . 0 1}$ & $t=-23.83$ & $<0.001$ & & & 239.89 & $<0.001$ \\
\hline \multicolumn{9}{|l|}{ Plants } \\
\hline Root survival E. atherica (\%) & & 0.08 & $z=3.03$ & $<0.01$ & & & 11.32 & $<0.001$ \\
\hline Cover E. atherica (after 8 months) & $z=-5.56$ & $<0.001$ & $z=-7.70$ & $<\mathbf{0 . 0 0 1}$ & $z=5.04$ & $<0.001$ & 83.05 & $<\mathbf{0 . 0 0 1}$ \\
\hline Cover E. atherica (after 2 years) & $z=-9.39$ & $<0.001$ & $z=-2.51$ & 0.01 & & & 46.07 & $<0.001$ \\
\hline Cover short-statured grasses (after 2 years) & $z=8.34$ & $<\mathbf{0 . 0 0 1}$ & $z=3.99$ & $<\mathbf{0 . 0 0 1}$ & $z=-4.67$ & $<\mathbf{0 . 0 0 1}$ & 50.9 & $<0.001$ \\
\hline \multicolumn{9}{|l|}{ Fauna } \\
\hline Epigeic fauna abundance (Sept) & $z=-4.50$ & $<0.001$ & $z=-3.48$ & $<\mathbf{0 . 0 0 1}$ & & & 24.01 & $<0.001$ \\
\hline Micro-arthropods abundance (June) & & 0.06 & $z=-2.23$ & 0.03 & & & 54.96 & $<0.001$ \\
\hline Micro-arthropods species richness (June) & & & & & & & 22.19 & $<\mathbf{0 . 0 0 1}$ \\
\hline Micro-arthropods abundance (Sept) & $z=2.17$ & 0.03 & $z=-3.65$ & $<\mathbf{0 . 0 0 1}$ & $z=-3.36$ & $<0.001$ & 84.55 & $<0.001$ \\
\hline Micro-arthropods species richness (Sept) & & 0.14 & $z=-2.89$ & $<0.01$ & $z=-2.6$ & $<0.01$ & 99.24 & $<0.001$ \\
\hline Macro-detritivore abundance (log transf.) & $t=-3.67$ & 0.001 & $t=2.38$ & 0.03 & & & 15.00 & $<0.001$ \\
\hline
\end{tabular}

The grazed treatment was omitted for this analysis. Only significant $(P<0.05$; denoted bold) or marginally significant $(P<0.1)$ effects are shown, but marginally significant effects $(0.05<P<0.1)$ were not included in the final models. A significant effect of depth was found for micro-arthropod abundance and species richness in both periods (abundance June $z=-12.33, P<0.001$; richness June $z=-4.4, P<0.001$; abundance September $z=-9.88, P<0.001 ;$ richness September $z=-6.82, P<0.001$ ).

in September than in June and was increased by compaction during both periods (Table 2, Figure $1 \mathrm{~b}, \mathrm{e})$. The grazed reference plots had higher moisture content in June (Figure $1 \mathrm{~b}$, all treatments $P<0.001$ ), but somewhat lower moisture contents in September (Figure le, all treatments $P<0.01)$. Soil bulk density was slightly increased by defoliation in June, but increased by both compaction and defoliation in September (Table 2; Figure 1c, f). In neither period did bulk density of any of the treated plots approach that of the grazed plots (all treatments in both periods $P<0.01$; Figure 1c, f). Salt concentration of the pore water was approximately doubled by defoliation as well as compaction and was hence quadrupled in the $\mathrm{D}+\mathrm{C}$ plots (Table 2, Online Appendix B, Figure $\mathrm{B} 1)$. The salt concentration under grazing was, however, equal to that of the control plots $(t=0.14, P=0.89)$.
Soil redox potential showed a significant threeway interaction between depth, defoliation, and compaction $(t=2.55, P=0.01)$, therefore analyses were performed separately for each stratum. Defoliation caused a reduction in soil redox potential by some $50 \mathrm{mV}$, but compaction caused a decrease by more than $150 \mathrm{mV}$ at $2 \mathrm{~cm}$, increasing to more than $200 \mathrm{mV}$ at 5 and $10 \mathrm{~cm}$ depth (Table 2; Figure 2). Redox potential in the grazed marsh was equal to that of the $\mathrm{C}$ and $\mathrm{D}+\mathrm{C}$ plots $(P>0.06$ at all depths), and thus significantly lower than in the $\mathrm{D}$ and control plots $(P<0.01)$ at all depths (Figure 2).

\section{Plants}

Soil compaction caused a significant increase in root mortality of $E$. atherica during winter after the treatments commenced (Table 2; Figure B2). This was especially severe in the $\mathrm{D}+\mathrm{C}$ plots, where 

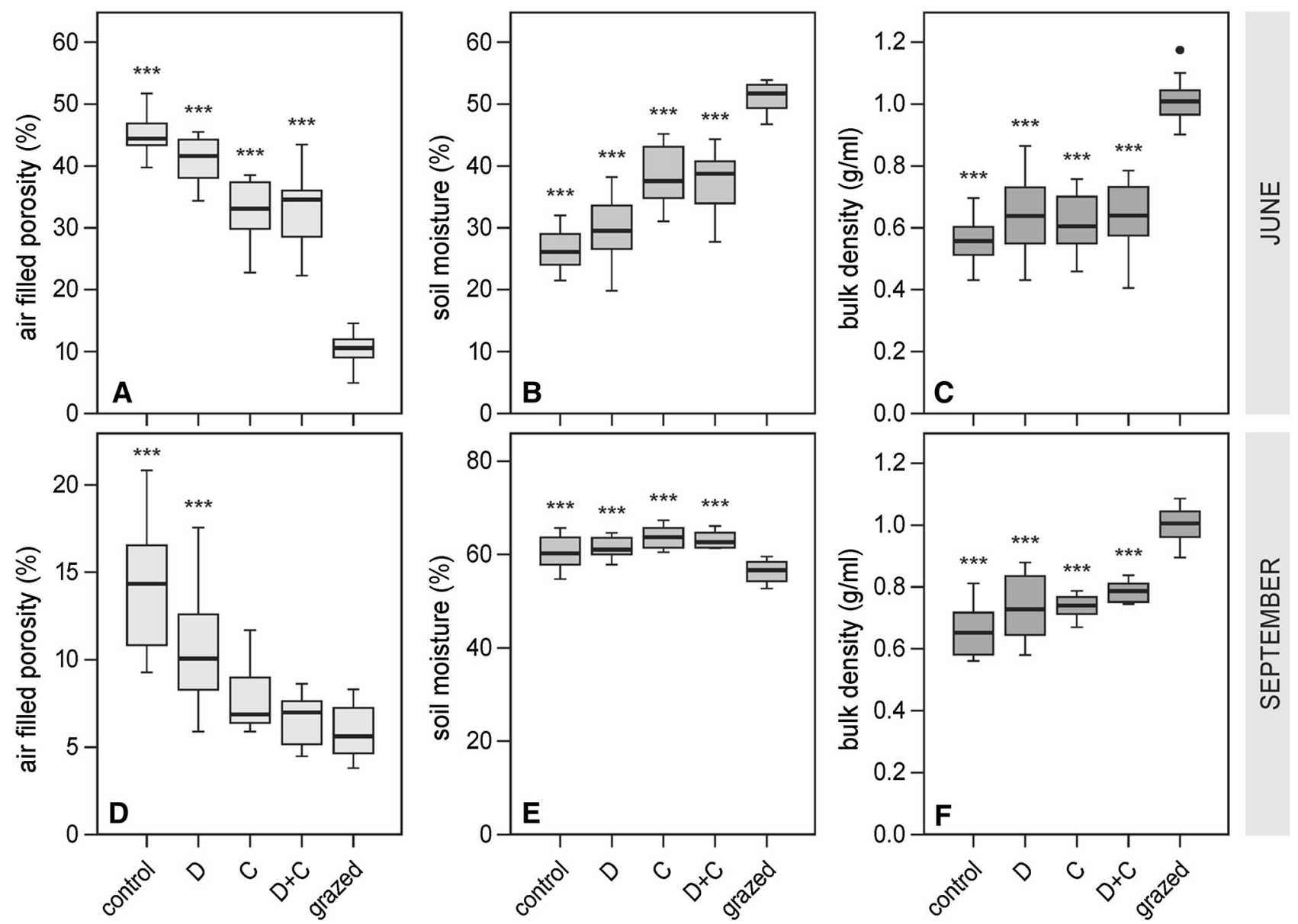

Figure 1. Effects of soil compaction (rammer), defoliation (monthly mowing), and long-term grazing ( $1 \mathrm{cow}^{-1}$ ) on soil physical properties in a temperate salt marsh with heavy clay soil. Measurements were taken under dry conditions (June) and waterlogged conditions (September), 1 year after the start of the experimental treatments. $* * * / * * *$ indicate significant difference from the grazed treatment: ${ }^{*} P<0.05,{ }^{* *} P<0.01,{ }^{* *} P<0.001$. D defoliated, $C$ compacted, D + C: defoliated + compacted.

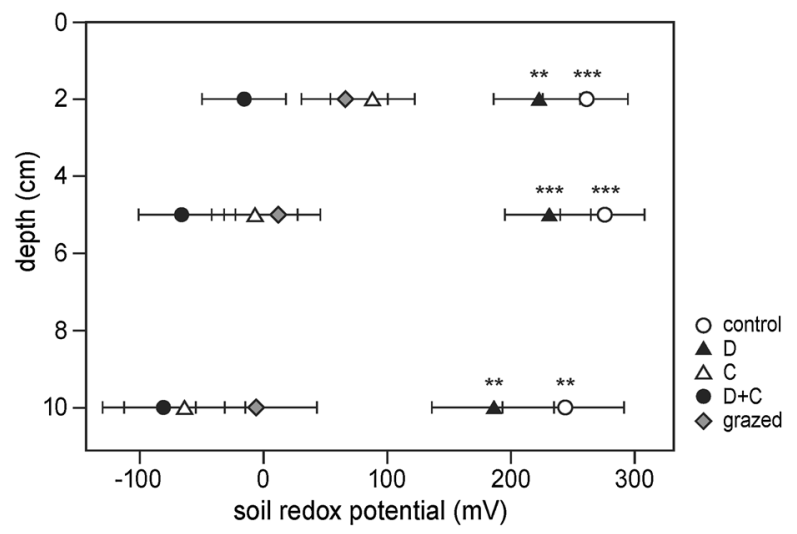

Figure 2. Effects of soil compaction, defoliation, and grazing on soil redox potential in September 2011 (mean $\pm \mathrm{SE}$ ), 1 year after the start of the experiment. Stars denote significant differences with the grazed plots. Abbreviations and significance as in Figure 1. only $50 \%$ of the roots survived, whereas in the control plots $90 \%$ survived. Defoliation had a marginally significant negative effect on root survival (Table 2).

Eight months after the start of the experiment, cover of E. atherica was severely reduced by both defoliation and compaction (Table 2; Figure 3a). After 2 years, however, E. atherica had recovered to approximately $90 \%$ of its initial cover in the C plots, whereas in the $\mathrm{D}$ and $\mathrm{D}+\mathrm{C}$ plots it had decreased to $10-20 \%$ cover (Figure 3a). By contrast, grazing-tolerant short-statured grasses increased over the course of the experiment. Eight months after compaction, there was no difference in the cover of short-statured grasses between any of the treatments $\left(\chi^{2}=1.90, P=0.37\right.$, Figure $\left.3 b\right)$, but after 2 years significant differences had developed (Table 2; Figure 3b). Cover of short-statured grasses was the highest in the D plots, followed by 


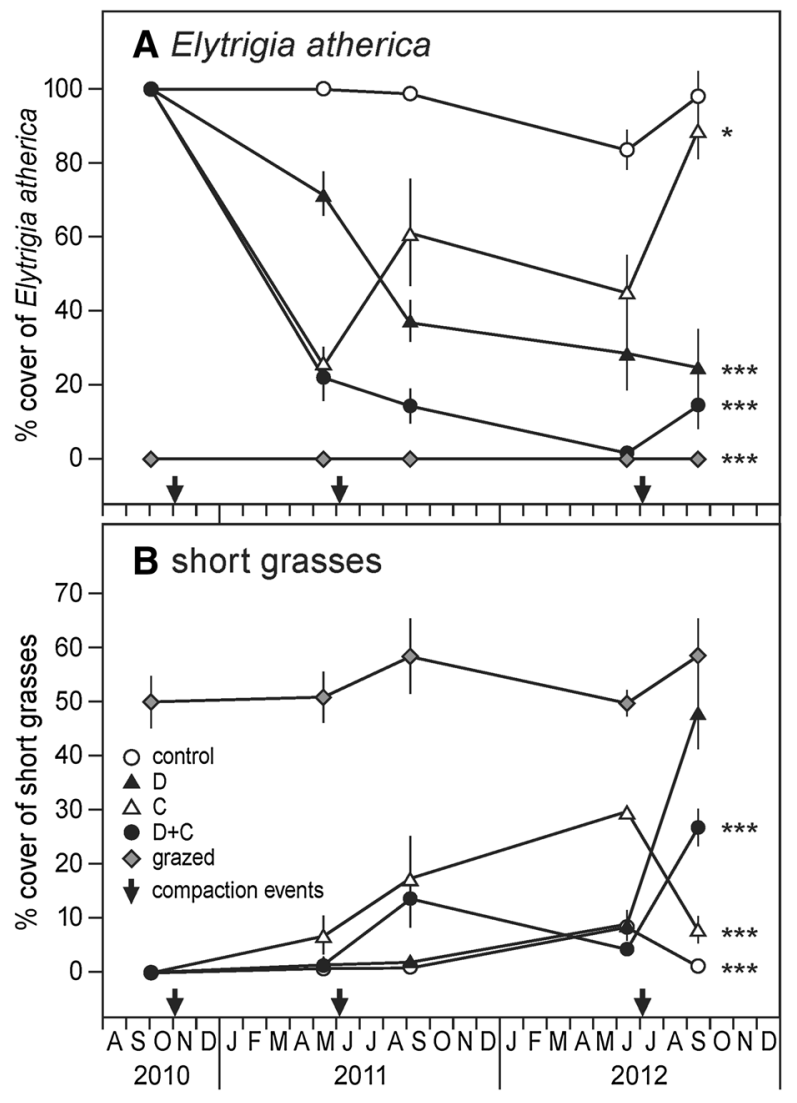

Figure 3. Development of average cover percentage of $\mathbf{A}$ the tall grass $E$. atherica and $\mathbf{B}$ the grazing-tolerant short grasses A. stolonifera, F. rubra, and Pu. maritima under defoliation, soil compaction (see arrows) and grazing over 2 years (mean $\pm \mathrm{SE}$ ). In $\mathbf{A}$ stars denote significant differences from the control and in $\mathbf{B}$ significant differences from the grazed plots after 2 years. Abbreviations and significances as in Figure 1.

the $\mathrm{D}+\mathrm{C}$ plots, whereas their cover was low in the $\mathrm{C}$ and control plots (Figure $3 \mathrm{~b}$ ), explaining a significant interaction between compaction and defoliation (Table 2). Bare soil percentage in both the $\mathrm{C}$ and the $\mathrm{D}+\mathrm{C}$ plots was up to $30 \% 8$ months after compaction, and up to $60 \%$ in the $\mathrm{D}+\mathrm{C}$ plots after 1 year. In the D plots, bare soil peaked 1 year after compaction, reaching on average $27 \%$ cover.

The plant communities replacing E. atherica differed significantly between treatments (halophytes: $\chi^{2}=50.35, \quad P<0.001 ;$ glycophytes: $\chi^{2}=37.18$, $P<0.001$; Figure 4). Halophyte cover increased in the $\mathrm{D}+\mathrm{C}$ plots to a level equal to that of the grazed marsh, whereas glycophyte cover was increased in the $\mathrm{D}$ and $\mathrm{D}+\mathrm{C}$ plots and was equal to the grazed marsh only in the D plots (Figure 4).

Two years after the start of the experiment, $62 \%$ of changes in plant species composition could be explained by defoliation (MANOVA; $R^{2}=0.58$ )

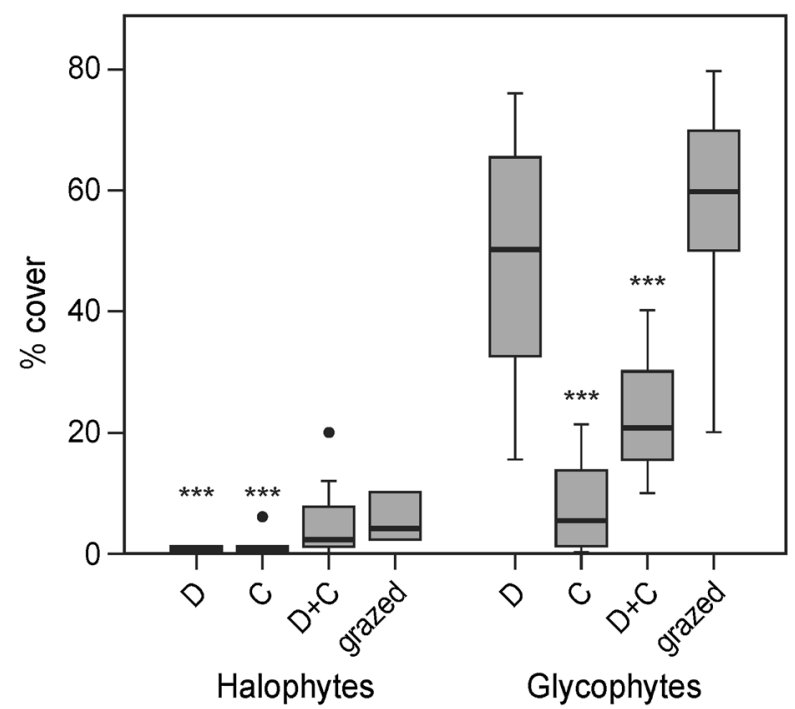

Figure 4. Plant communities replacing E. atherica in the treated plots, after 2 years of monthly mowing and three compaction rounds, compared to grazed conditions. Halophytes: P. maritima, S. maritima, S. europaea; Glycophytes: A. stolonifera, F. rubra, T. maritimum, P. aviculare; not included: E. atherica, A. tripolium, Pl. maritima, A. prostrata. Abbreviations and significances in comparison to the grazed plots as in Figure 1.

and compaction (MANOVA; $R^{2}=0.04$, Table 3), although the effect of compaction was only marginally significant $(P=0.08)$. NMDS of plant communities shows a directional trend of the communities of the D, C, and D + C plots toward the grazed plots (Figure 5a). The grazed plots, however, remain distinctly different from any of the other treatments due to the presence of several species not present at the location of the experiment, such as Pl. maritima and G. maritima.

\section{Fauna}

Abundance of epigeic fauna was significantly decreased by compaction, but more so by defoliation (Table 2; Figure 6a). Under grazed conditions, however, the abundance of epigeic arthropods was as high as in the control treatment (Figure 6a), but community composition under grazing differed considerably from all treatments (Figure 5b). MANOVA showed that community composition of epigeic fauna was significantly affected by defoliation (Table 3; Figure 5b) and was marginally significantly affected by compaction $(P=0.09)$.

Species richness and abundance of soil microarthropods were significantly lower at $5-10 \mathrm{~cm}$ depth than at $0-5 \mathrm{~cm}$, in all treatments, under both dry and waterlogged conditions (Table 2; 
Table 3. Multivariate Permutational ANOVA Results Showing the Relative Importance of Defoliation and Soil Compaction and Their Interaction in Determining Species Composition of Plants (After 2 Years), Epigeic Fauna, and Soil Micro-arthropods (After 1 Year)

\begin{tabular}{|c|c|c|c|c|c|c|c|c|c|}
\hline & \multicolumn{3}{|c|}{ Defoliation } & \multicolumn{3}{|c|}{ Compaction } & \multicolumn{3}{|c|}{$\begin{array}{l}\text { Defoliation* } \\
\text { compaction }\end{array}$} \\
\hline & $F$ & $P$ & $R^{2}$ & $F$ & $P$ & $R^{2}$ & $F$ & $P$ & $R^{2}$ \\
\hline Plants & 44.87 & $<0.001$ & 0.58 & 3.28 & 0.08 & 0.04 & & & \\
\hline Epigeic fauna & 4.30 & $<0.001$ & 0.13 & 1.65 & 0.07 & 0.05 & & & \\
\hline Soil micro-arthropods $0-5 \mathrm{~cm}$ depth & & & & 6.54 & $<0.001$ & 0.17 & 1.84 & 0.06 & 0.05 \\
\hline Soil micro-arthropods $5-10 \mathrm{~cm}$ depth & & & & 5.89 & $<0.001$ & 0.16 & & & \\
\hline
\end{tabular}

Grazed plots were excluded from this analysis. Only significant $(P<0.05$; denoted bold $)$ or marginally significant $(P<0.1)$ effects are shown, but marginally significant effects $(0.05<P<0.1)$ were not included in the final models.
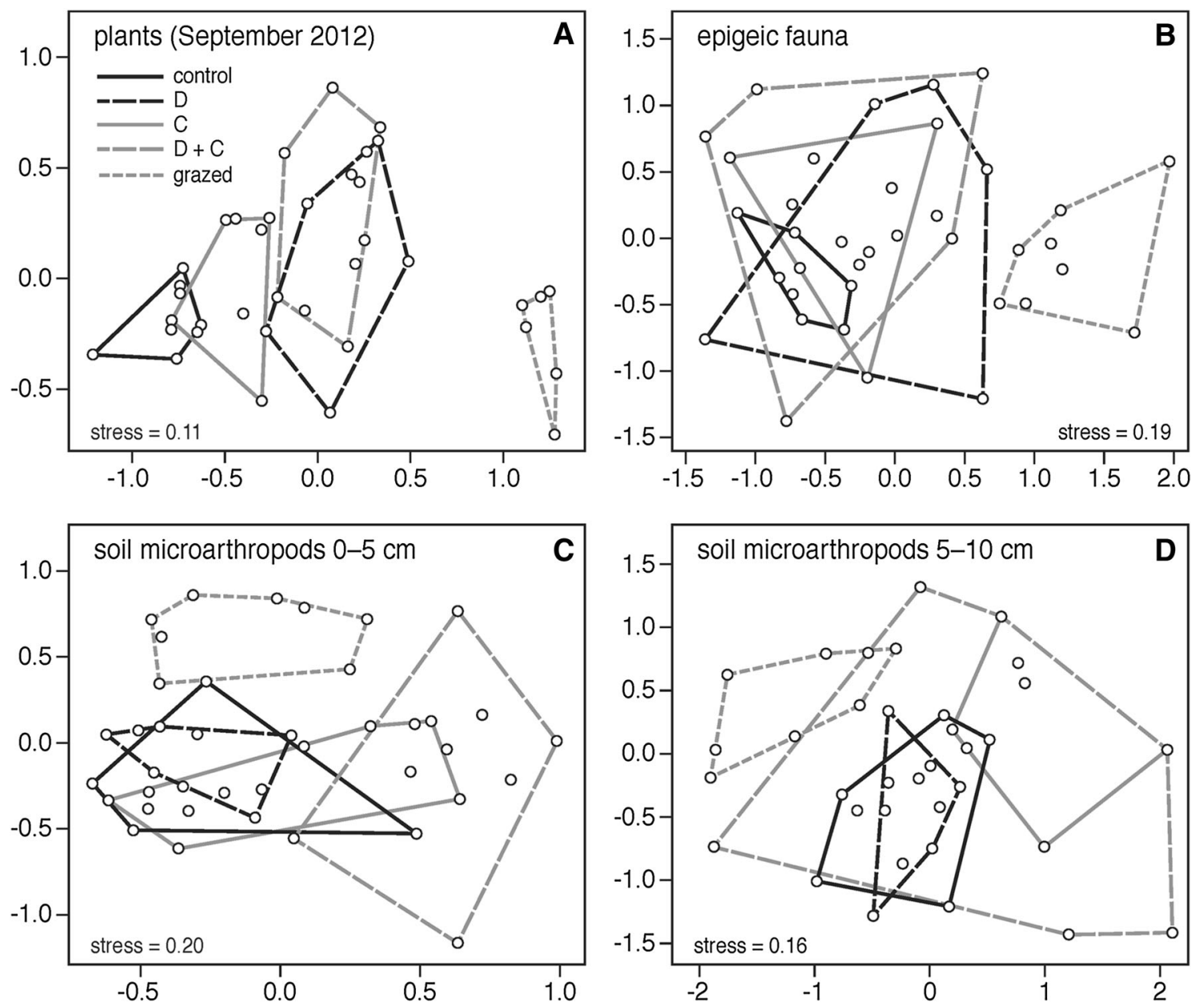

Figure 5. Biplots of first two NMDS axes of A plants, B epigeic fauna (beetles and spiders), and soil micro-arthropods (Collembola and Acari) at depths of $\mathbf{C} 0-5 \mathrm{~cm}$ and D $5-10 \mathrm{~cm}$ in reaction to defoliation (monthly mowing), soil compaction, and long-term grazing. Plant species composition was assessed 2 years, and animal communities 1 year after the start of the experiment. Abbreviations as in Figure 1.

Figure 6b, c, e, f), but depth had no significant interactive effect with compaction or defoliation (Table 2). In June, the abundances were sig- nificantly decreased by compaction and marginally increased by defoliation (Table 2; Figure 6b), but there was no difference in species richness between 

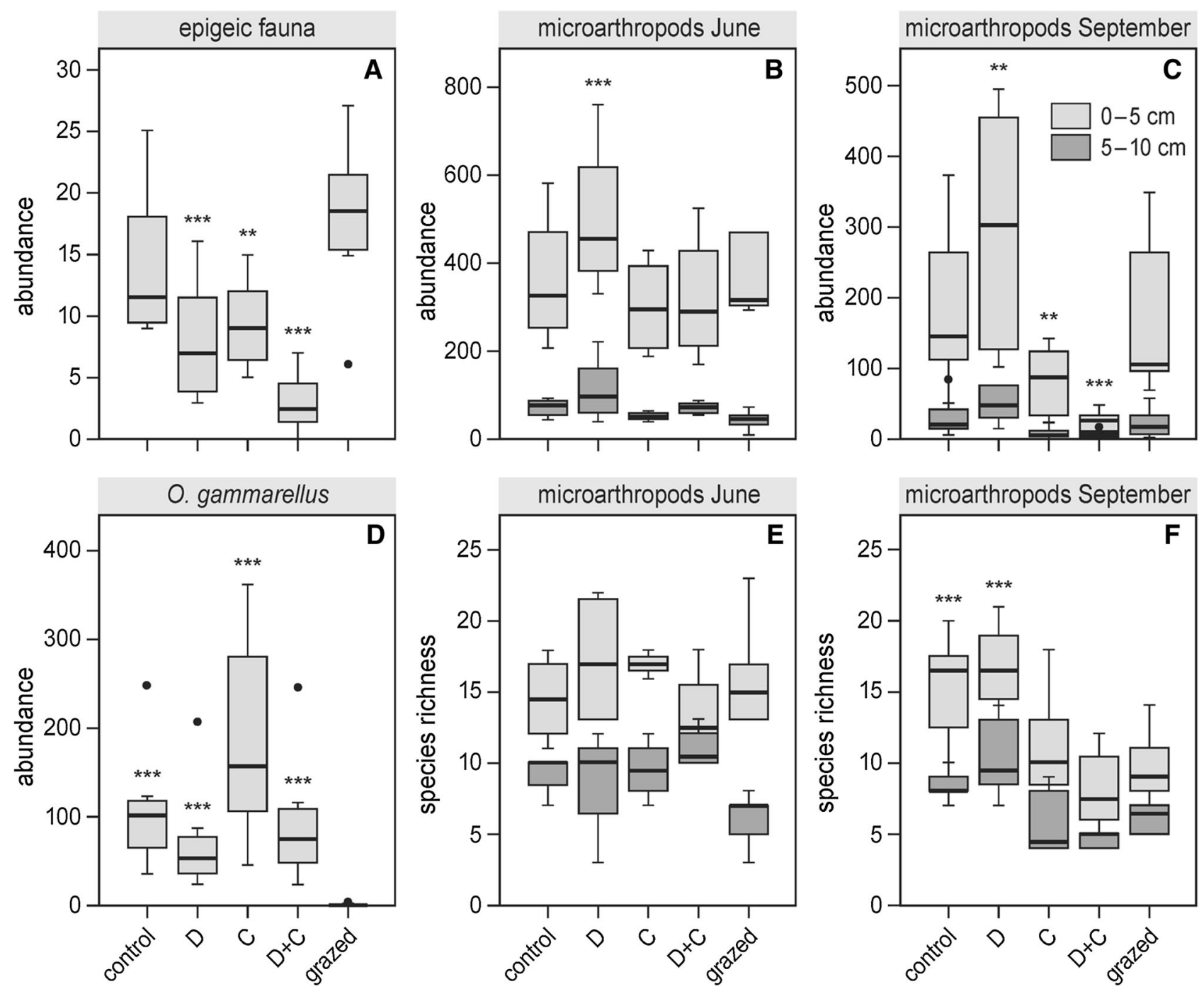

Figure 6. Effects of soil compaction, defoliation, and grazing on abundance of A epigeic fauna (spiders and beetles), D the crustacean macro-detritivore Orchestia gammarellus, and B, C, E, F abundance and richness of soil micro-arthropods (Collembola and Acari). Abbreviations and significances in comparison to the grazed plots as in Figure 1.

any of the treatments at either depth $(0-5 \mathrm{~cm}$ : $\chi^{2}=3.1, \quad P=0.54 ; \quad 5-10 \mathrm{~cm}: \chi^{2}=6.0, \quad P=0.20$, Figure 6e). When compared to the grazed marsh, only a higher abundance of micro-arthropods was present in the D plots, whereas no differences were found in species richness for any of the treated plots.

In September, however, micro-arthropod abundance and species richness were significantly reduced by soil compaction, but increased by defoliation in the absence of compaction (Table 2; Figure $6 \mathrm{c}, \mathrm{f})$. Compared to the grazed marsh, micro-arthropod abundance was higher in the D plots $(z=2.80, P<0.01)$, but lower in the C- $(z=$ -3.22, $P=0.001)$ and $\mathrm{D}+\mathrm{C}(z=-5.9, P<0.001)$ plots, and did not differ from the control plots
$(P=0.57$; Figure $6 \mathrm{c})$. Species richness, however, was lower in the grazed plots than in the control $(z=3.3, \quad P=0.001)$ and D plots $(z=4.7, \quad P<$ $0.001)$, but equal to the $\mathrm{C}(P=0.67)$ and $\mathrm{D}+\mathrm{C}$ plots $(P=0.09)$ (Figure 6f).

MANOVA showed that compaction was a highly significant factor in explaining community composition of soil micro-arthropods (Table 3), and the interaction between defoliation and compaction was marginally significant for the upper stratum $(P=0.06)$. The explanatory power of the models, however, was rather low $\left(0-5 \mathrm{~cm}: R^{2}=0.18\right.$; $5-10 \mathrm{~cm}: R^{2}=0.16$ ), which is also evident from the high stress of the NMDS biplots (Figure 5c, d). NMDS of the micro-arthropod communities showed high similarity between the control and the 
D plots, and a shift in composition of the $\mathrm{C}$ and $\mathrm{D}+\mathrm{C}$ plots (Figure $5 \mathrm{c}, \mathrm{d}$ ), whereas the grazed plots were distinctly different from all other plots.

CWM body size of both Collembola and Acari was smaller in the lower soil stratum in both periods. This caused a significant interaction between depth, defoliation, and compaction for Collembola in June $(t=3.28, \quad P<0.01)$, and therefore the effects were analyzed separately for each stratum (Table Bl). Compaction caused a significant decrease in CWM body length in September of $0.8 \mathrm{~mm}$ for Collembola and $0.04 \mathrm{~mm}$ for the much smaller Acari (Table B2). In June, defoliation caused a significant increase in Collembola body length, but a negative interaction with defoliation (Table B1), giving a net decrease in the D $+\mathrm{C}$ plots (Table B2). In comparison to the grazed marsh, Collembola in June showed a significantly lower CWM body size only in the D + C plots in the upper stratum, and all treated plots had higher CWM body size in the lower stratum (Table B2), whereas Acari showed no differences. In September, Collembola CWM body size was smaller in all experimental plots over both strata in comparison to the grazed marsh, and Acari only showed a smaller CWM body size in the experimental plots in the upper stratum (Table B2).

The macro-detritivore $O$. gammarellus did not follow our hypothesized decrease in response to soil compaction. It was positively affected by soil compaction, but negatively affected by defoliation (Table 2) and was virtually absent under cattle grazing (Figure 6d).

\section{Discussion}

Our results confirmed most of our expectations regarding the simulated large herbivore effects of defoliation and soil compaction treatments on soil, plants, and soil arthropods. As expected, defoliation had no large impact on soil properties, but caused an increase in cover of short-statured plants and a decrease in abundance of epigeic fauna. The effects of soil compaction were most pronounced under waterlogged conditions, showing increased soil moisture content, and decreased air-filled porosity and redox potential, as well as abundance and species richness, and a reduction in body size of soil micro-arthropod communities. Only combined defoliation and soil compaction caused the expected increase in soil salt concentration and cover of halophytes. Defoliation, therefore, seems to be conditional for soil compaction to have an effect on plant communities. Surprisingly, we did not find a negative effect of soil compaction on macro-detri- tivores, and also the comparison of our treatments to the grazed marsh yielded mixed results.

We had hypothesized that due to the collapse of pore space, macro-detritivores would be excluded from the compacted plots (see for example, Piearce 1984; Schon and others 2010). The most important macro-detritivore in this ecosystem, the terrestrial amphipod $O$. gammarellus, is well known to be almost completely absent from grazed salt marshes with short vegetation and highly compacted soils (Meyer and others 1995; Schrama and others 2013a). In the current study, however, we found that the abundance of this species increased under compaction, but decreased under defoliation. It is likely that in the $\mathrm{C}$ plots, the amount of fresh, highquality plant litter was increased. As this species relies on large quantities of dead organic matter (Dias and Sprung 2003) and uses protective vegetation cover to maintain its homeostasis (Moore and Francis 1986), our C treatment has likely benefited this species through increased food and shelter availability. By contrast, defoliation decreased both food and shelter availability, causing a decrease in macro-detritivore abundance. The small scale of our experiment and the absence of a physical barrier for this species, which can travel up to $10 \mathrm{~m}$ per night (M.P. Berg, unpublished data), enabled this species to quickly colonize the treated plots from the surrounding vegetation. It can be expected that in the long run, a combination of defoliation and compaction will result in strongly reduced macro-detritivore abundance due to habitat deterioration.

Micro-arthropod abundance and species richness were strongly reduced as a result of soil compaction, but only under waterlogged conditions. Collembola in particular almost completely disappeared from the deeper stratum of all compacted plots, and therefore seem to be more sensitive to soil compaction than the smaller-sized Acari, in agreement with previous studies (King and Hutchinson 1976; Aritajat and others 1977; Heisler 1994). Surprisingly, abundance and species richness of microarthropods increased significantly in the D plots. An increase in soil fauna abundance following defoliation has been previously observed (Jensen and others 1973) and it is likely that this is caused by an increase in litter quality, root exudation, and/or an increase in soil temperature. Increased litter quality and root exudation result in a higher microbial biomass, an important food source for microarthropods (Hopkin 2007). An increase in temperature may result in enhanced growth rates, shorter time to reach maturity and, hence, a higher reproductive output (Christiansen 1964). 


\section{Comparison to Grazed Conditions}

Several soil properties, such as soil aeration and redox potential, of the grazed marsh were similar in the $\mathrm{C}$ and $\mathrm{D}+\mathrm{C}$ plots, especially under waterlogged conditions, and the cover of halophytes reached levels comparable to grazed conditions in the $\mathrm{D}+\mathrm{C}$ plots. Although our treatments had strong effects on soil properties, floral composition and soil fauna, our success in replicating the conditions of the long-term cattle-grazed salt marsh was limited. In multivariate space, the plant community showed a directional change toward longterm grazed conditions, but did not match it. Indeed, when comparing vegetation in our treated plots to adjacent salt marshes where grazing was installed 3 years previously (S. Nolte unpublished data), an obvious similarity with the $\mathrm{D}+\mathrm{C}$ plots becomes apparent, whereas the $\mathrm{D}$ plots appear distinctly different (Figure B3). This suggests that our $\mathrm{D}+\mathrm{C}$ treatment is probably more comparable to the salt marshes where grazing just commenced. Nevertheless, soil bulk density was only slightly increased by our treatments, not nearly reaching the level of the long-term grazed salt marsh, and soil salt concentrations in the experimental plots were 2-4 times higher than under grazed conditions. Additionally, the plant and arthropod communities in all our treated plots showed considerable compositional differences with those under grazing.

Three main factors may explain these mixed results. First, the spatiotemporal scale of the treatments was not comparable to that of a salt marsh that has been grazed for decades, and to which plant and arthropod communities have had time to adapt. The difficulty here is that it is impossible to compact the soil without physically damaging the plants growing in it. To allow the plants to recover from our intense compaction treatment, we employed it with low frequency, resulting in representative soil properties, but a time lag in response of the plant and arthropod communities.

Secondly, due to the isolation and small scale of our plots, only a selection of the species already present in the ungrazed area could have occurred. Several plant and arthropod species found in the grazed salt marsh will have been dispersal limited, explaining the consistent dissimilarity in species composition between the grazed and treated plots (see also Dobarro and others 2013).

Finally, the present stocking density of 1 cow ha ${ }^{-1}$ at the grazed marsh was probably somewhat lower than in the recent history of the area, allowing a closed vegetation cover to establish. This will have affected salt concentrations because these are well known to correlate positively with bare soil percentage (Lavado and Taboada 1987; Srivastava and Jefferies 1996). The conditions in the D + C plots were therefore probably more comparable to other, more intensively grazed salt marshes (Bakker and others 1985; Srivastava and Jefferies 1996; Esselink and others 2000).

\section{The Importance of Defoliation and Trampling}

The effects of defoliation on plants and epigeic arthropods are generally well understood (Morris 2000; Mikola and others 2009). Defoliation allows plant species richness to increase after removal of competitively dominant species, in our case $E$. atherica, a species of low resource quality. Epigeic and foliar arthropods usually decrease in abundance due to a decrease in vegetation complexity. Its effects on belowground fauna are more complex, and can be positive to some taxa, while being negative to others (for example, Mikola and others 2009; Schon and others 2010).

The effects of trampling, however, seem to differ between ecosystems, when our results are compared to those of similar experiments. In unproductive ecosystems with coarse-textured soils, the majority of trampling effects on vegetation composition were explained by biomass destruction of the most competitive species (Olofsson and Shams 2007; Sørensen and others 2009; Dobarro and others 2013), and no differences in soil properties caused by the treatments were reported (Sørensen and others 2009; Dobarro and others 2013). By contrast, on our fine-textured, highly productive clay soil, trampling only reduced cover of the most competitive species (E. atherica) during the first round of compaction, after which it rebounded and remained dominant. Only when defoliation preceded soil compaction did we attain abiotic conditions comparable to those of grazed salt marshes, and a decrease in cover of E. atherica. This corroborates previous findings that the effects of soil compaction are most severe on fine-textured soils (Schrama and others 2013a, b; Veldhuis and others 2014).

Negative impacts of litter trampling (Duffey 1975) and soil compaction (Chappell and others 1971; King and Hutchinson 1976; Petersen and others 2004; Schon and others 2010) on soil fauna are commonly found, although some positive effects have been reported (Bardgett and others 1993). It therefore seems that the negative effects of trampling may to some extent be alleviated by 
the positive effects of increased nutrient input due to defecation, radial oxygen loss, root exudation, and greater root penetration (Bardgett and Wardle 2003). Thus, the net impact of grazing on soil fauna and the processes they mediate depends on herbivore density and the spatial and temporal scales at which grazing takes place. In productive ecosystems, such as ours, the effects of trampling can be expected to be severe, as the fast regrowth of the vegetation allows high herbivore densities and frequent returns to the same feeding station.

At our grazed site, where livestock densities were moderate, it is possible that the positive and negative effects of grazing were balanced out, which may explain why no difference in abundance and only a small difference in community composition of soil micro-arthopods were found between the grazed and control plots.

Because soil fauna is important in decomposition and mineralization processes (Seastedt 1984), low abundance and diversity of soil fauna can explain observations of decreased mineralization and decomposition, often found on grazed salt marshes (Kiehl and others 2001; Ford and others 2012; Schrama and others 2013a). However, to fully understand the mechanisms by which soil compaction affects ecosystems, it will be important to study the complex mutualistic and antagonistic relations between microbes, plants, and soil fauna, which can be mediated by soil compaction (Kardol and others 2014).

We conclude that herbivore-induced soil compaction should be seen as an additional mechanism explaining changes in plant and soil fauna communities under grazing. Its importance, however, depends to a large extent on ecosystem productivity, soil physical properties, and herbivore density.

\section{ACKNOWLEDGMENTS}

We thank Corinna Rickert, Mark Eerkens, Sytse Kooistra, Daan Schrama, and Gerda Marijs for help in the field, and Wim Dimmers and Oscar Vorst for assistance with identifications of mites and beetles, respectively. We also thank Fons van der Plas, two anonymous reviewers and the subject editor for thoughtful comments on previous versions of this manuscript. Finally, we thank It Fryske Gea for permission to perform this experiment on their lands. This study was funded by Het Waddenfonds (WF 200451).

\section{OPEN ACCESS}

This article is distributed under the terms of the Creative Commons Attribution License which permits any use, distribution, and reproduction in any medium, provided the original author(s) and the source are credited.

\section{REFERENCES}

Aritajat U, Madge DS, Gooderham PT. 1977. Effects of compaction of agricultural soils on soil fauna.1. Field investigations. Pedobiologia 17:262-82.

Bakker JP, Dijkstra M, Russchen PT. 1985. Dispersal, germination and early establishment of halophytes and glycophytes on a grazed and abandoned salt-marsh gradient. New Phytol 101:291-308.

Bardgett RD, Frankland JC, Whittaker JB. 1993. The effects of agricultural management on the soil biota of some upland grasslands. Agric Ecosyst Environ 45:25-45.

Bardgett RD, Wardle DA. 2003. Herbivore-mediated linkages between aboveground and belowground communities. Ecology 84:2258-68.

Bates D, Maechler M, Bolker B, Walker S. 2014. lme4: linear mixed-effects models using Eigen and S4_. R package version 1.1-7. http://cran.r-project.org/package=lme4.

Bazelmans J, Meier D, Nieuwhof A, Spek T, Vos P. 2012. Understanding the cultural historical value of the Wadden Sea region. The co-evolution of environment and society in the Wadden Sea area in the Holocene up until early modern times $(11,700$ BC-1800 AD): an outline. Ocean Coast Manag 68:114-26.

Beylich A, Oberholzer H-R, Schrader S, Hoeper H, Wilke B-M. 2010. Evaluation of soil compaction effects on soil biota and soil biological processes in soils. Soil $\&$ Tillage Research 109:133-43.

Borer ET, Seabloom EW, Gruner DS, Harpole WS, Hillebrand H, Lind EM, Adler PB, Alberti J, Anderson TM, Bakker JD, Biederman L, Blumenthal D, Brown CS, Brudvig LA, Buckley YM, Cadotte M, Chu C, Cleland EE, Crawley MJ, Daleo P, Damschen EI, Davies KF, DeCrappeo NM, Du G, Firn J, Hautier Y, Heckman RW, Hector A, HilleRisLambers J, Iribarne O, Klein JA, Knops JMH, La Pierre KJ, Leakey ADB, Li W, MacDougall AS, McCulley RL, Melbourne BA, Mitchell CE, Moore JL, Mortensen B, O'Halloran LR, Orrock JL, Pascual J, Prober SM, Pyke DA, Risch AC, Schuetz M, Smith MD, Stevens CJ, Sullivan LL, Williams RJ, Wragg PD, Wright JP, Yang LH. 2014. Herbivores and nutrients control grassland plant diversity via light limitation. Nature 508:517-20.

Breland TA, Hansen S. 1996. Nitrogen mineralization and microbial biomass as affected by soil compaction. Soil Biol Biochem 28:655-63.

Chappell HG, Ainsworth JF, Cameron RAD, Redfern M. 1971. The effect of trampling on a chalk grassland ecosystem. J Appl Ecol 8:869-82.

Christiansen K. 1964. Bionomics of collembola. Annu Rev Entomol 9:147-78.

Cole L, Buckland SM, Bardgett RD. 2008. Influence of disturbance and nitrogen addition on plant and soil animal diversity in grassland. Soil Biol Biochem 40:505-14.

Davy AJ, Brown MJH, Mossman HL, Grant A. 2011. Colonization of a newly developing salt marsh: disentangling independent effects of elevation and redox potential on halophytes. J Ecol 99:1350-7.

Di HJ, Cameron KC, Milne J, Drewry JJ, Smith NP, Hendry T, Moore S, Reijnen B. 2001. A mechanical hoof for simulating 
animal treading under controlled conditions. N Z J Agric Res 44:111-16.

Dias N, Sprung M. 2003. Population dynamics and production of the amphipod Orchestia gammarellus (Talitridae) in a Ria Formosa saltmarsh (southern Portugal). Crustaceana 76:1123-41.

Dobarro I, Carmona CP, Peco B. 2013. Dissecting the effects of simulated cattle activity on floristic composition and functional traits in Mediterranean grasslands. PLoS One 8:e79822.

Duffey E. 1975. The effects of human trampling on the fauna of grassland litter. Biol Conserv 7:255-74.

Esselink P, Zijlstra W, Dijkema KS, van Diggelen R. 2000. The effects of decreased management on plant-species distribution patterns in a salt marsh nature reserve in the Wadden Sea. Biol Conserv 93:61-76.

Fjellberg A. 1998. The Collembola of Fennoscandia and Denmark part I: Poduromorpha. Leiden: Brill.

Fjellberg A. 2007. The Collembola of Fennoscandia and Denmark part II: Entomobryomorpha and Symphypleona. Leiden: Brill.

Ford H, Garbutt A, Jones L, Jones DL. 2012. Methane, carbon dioxide and nitrous oxide fluxes from a temperate salt marsh: grazing management does not alter global warming potential. Estuar Coast Shelf Sci 113:182-91.

Freude H, Harde KW, Lohse GA, Klausnitzer B (eds). 19651999. Die Käfer Mitteleuropas bd 1-15. Krefeld: Goecke \& Everts.

Garnier E, Cortez J, Billès G, Navas M-L, Roumet C, Debussche M, Laurent G, Blanchard A, Aubry D, Bellmann A, Neill C, Toussaint J-P. 2004. Plant functional markers capture ecosystem properties during secondary succession. Ecology $85: 2630-7$.

Hamilton EW, Frank DA. 2001. Can plants stimulate soil microbes and their own nutrient supply? Evidence from a grazing tolerant grass. Ecology 82:2397-402.

Hamza MA, Anderson WK. 2005. Soil compaction in cropping systems-a review of the nature, causes and possible solutions. Soil Tillage Res 82:121-45.

Heisler C. 1994. Effects of soil compaction on soil mesofauna (Collembola and Gamasina)-a 3-year field study. Pedobiologia 38:566-76.

Hobbs NT. 2006. Large herbivores as sources of disturbance in ecosystems. In: Danell K, Bergstrom R, Duncan P, Pastor J, Eds. Large herbivore ecology, ecosystem dynamics and conservation. Cambridge: Cambridge University Press. p 261-88.

Holland JN, Cheng W, Crossley DA. 1996. Herbivore-induced changes in plant carbon allocation: assessment of belowground C fluxes using carbon-14. Oecologia 107:87-94.

Hopkin SP. 2007. A key to the Collembola (springtails) of Britain and Ireland. Shropshire: FSC Publications.

Horn R, Domzal H, Slowinskajurkiewicz A, Vanouwerkerk C. 1995. Soil compaction processes and their effects on the structure of arable soils and the environment. Soil Tillage Res 35:23-36.

Hughes AM. 1976. The mites of stored food and houses. Great Britain: Ministry of Agriculture, Fisheries and Food.

Jensen P, Jacobson GL, Willard DE. 1973. Effects of mowing and raking on Collembola. Ecology 54:564-72.

Kardol P, Dickie IA, St. John MG, Husheer SW, Bonner KI, Bellingham PJ, Wardle DA. 2014. Soil-mediated effects of invasive ungulates on native tree seedlings. J Ecol 102:62231.
Karg W. 1993. Acari (Acarina), Milben Parasitiformes (Anactinotrichaeta) Cohors Gamasina Leach. Raubmilben. New York: Gustav Fischer Verlag.

Kiehl K, Esselink P, Gettner S, Bakker JP. 2001. The impact of sheep grazing on net nitrogen mineralization rate in two temperate salt marshes. Plant Biol 3:553-60.

King KL, Hutchinson KJ. 1976. Effects of sheep stocking intensity on abundance and distribution of mesofauna in pastures. J Appl Ecol 13:41-55.

Kohler F, Gillet F, Gobat JM, Buttler A. 2004. Seasonal vegetation changes in mountain pastures due to simulated effects of cattle grazing. J Veg Sci 15:143-50.

Kohler F, Hamelin J, Gillet F, Gobat JM, Buttler A. 2005. Soil microbial community changes in wooded mountain pastures due to simulated effects of cattle grazing. Plant Soil 278:32740.

Krantz GW, Walter DE. 2009. A manual of acarology. 3rd edn. Lubbock: Texas Tech University Press.

Kuznetsova A, Brockhoff PB, Christensen BRH. 2014. lmerTest: Tests for random and fixed effects for linear mixed effect models version 2.0-11. http://cran.r-project.org/package $=$ lmerTest.

Laanbroek HJ. 1990. Bacterial cycling of minerals that affect plant-growth in waterlogged soils-a review. Aquat Bot 38:109-25.

Lavado RS, Taboada MA. 1987. Soil salinization as an effect of grazing in a native grassland soil in the Flooding Pampa of Argentina. Soil Use Manag 3:143-8.

Liddle M. 1997. Recreation ecology: the ecological impact of outdoor recreation and ecotourism. London: Chapman \& Hall.

Lipiec J, Hakansson I, Tarkiewicz S, Kossowski J. 1991. Soil physical properties and growth of spring barley as related to the degree of compactness of 2 soils. Soil Tillage Res 19:30717.

McNaughton SJ, Banyikwa FF, McNaughton MM. 1997. Promotion of the cycling of diet-enhancing nutrients by african grazers. Science 278:1798-800.

Van der Meijden R. 2005. Heukels' Flora van Nederland. Groningen/Houten: Wolters-Noordhof.

Meyer H, Fock H, Haase A, Reinke HD, Tulowitzki I. 1995. Structure of the invertebrate fauna in salt marshes of the Wadden Sea coast of Schleswig-Holstein influenced by sheepgrazing. Helgol Meeresunters 49:563-89.

Mikola J, Setala H, Virkajarvi P, Saarijarvi K, Ilmarinen K, Voigt W, Vestberg M. 2009. Defoliation and patchy nutrient return drive grazing effects on plant and soil properties in a dairy cow pasture. Ecol Monogr 79:221-44.

Moore PG, Francis CH. 1986. Environmental tolerances of the beach-hopper Orchestia gammarellus (Pallas) (Crustacea:Amphipoda). Marine Environ Res 19:115-29.

Morris MG. 2000. The effects of structure and its dynamics on the ecology and conservation of arthropods in British grasslands. Biol Conserv 95:129-42.

Nolte S, Müller F, Schuerch M, Wanner A, Esselink P, Bakker JP, Jensen K. 2013. Does livestock grazing affect sediment deposition and accretion rates in salt marshes? Estuar Coast Shelf Sci 135:296-305.

Oksanen J, Kindt R, Legendre P, O'Hara B, Simpson DL, Solymos P, M.Henry, H.Stevens, Wagner H, Guillaume Blanchet F, Minchin PR, O'Hara RG, Simpson GL, Henry M, Stevens H. 2014. vegan 2.1-4. Community Ecology Package. http:// 
CRANR-project.org $\mathrm{R}$ package. http://cran.r-project.org/ package $=$ vegan .

Olofsson J, Shams H. 2007. Determinants of plant species richness in an alpine meadow. J Ecol 95:916-25.

Petersen H, Jucevica E, Gjelstrup P. 2004. Long-term changes in collembolan communities in grazed and non-grazed abandoned arable fields in Denmark. Pedobiologia 48:559-73.

Piearce TG. 1984. Earthworm populations in soils disturbed by trampling. Biol Conserv 29:241-52.

Pinheiro J, Bates D, DebRoy S, Sarkar D, Team RDC. 2014. nlme: Linear and Nonlinear Mixed Effects Models. R package version 3.1-117. http://CRAN.R-project.org/package=nlme.

R Core Team. 2014. R: A language and environment for statistical computing. Vienna: R Foundation for Statistical Computing. Version 3.1.1.

Rasiah V, Kay BD. 1998. Legume N mineralization: effect of aeration and size distribution of water-filled pores. Soil Biol Biochem 30:89-96.

Roberts MJ. 1995. Spiders of Britain and Northern Europe. London: HarperCollins Publishers.

Schon NL, Mackay AD, Yeates GW, Minor MA. 2010. Separating the effects of defoliation and dairy cow treading pressure on the abundance and diversity of soil invertebrates in pastures. Appl Soil Ecol 46:209-21.

Schrama M, Heijning P, Bakker JP, Berg MP, Olff H. 2013a. Herbivore trampling as an alternative pathway for explaining differences in nitrogen mineralization in moist grasslands. Oecologia 172:231-43.
Schrama M, Veen GF, Bakker ES, Ruifrok JL, Bakker JP, Olff H. 2013b. An integrated perspective to explain nitrogen mineralization in grazed ecosystems. Perspect Plant Ecol Evol Syst 15:32-44.

Seastedt TR. 1984. The role of microarthropods in decomposition and mineralization processes. Annu Rev Entomol 29:25-46.

Sørensen LI, Mikola J, Kytoviita M-M, Olofsson J. 2009. Trampling and spatial heterogeneity explain decomposer abundances in a sub-arctic grassland subjected to simulated reindeer grazing. Ecosystems 12:830-42.

Srivastava DS, Jefferies RL. 1996. A positive feedback: herbivory, plant growth, salinity, and the desertification of an arctic saltmarsh. J Ecol 84:31.

Van Straalen NM, Rijninks PC. 1982. The efficiency of Tullgren apparatus with respect to interpreting seasonal-changes in age structure of soil arthropod populations. Pedobiologia 24:197209.

Trimble SW, Mendel AC. 1995. The cow as a geomorphic agent-a critical review. Geomorphology 13:233-53.

Van Klink R, Van der Plas F, Van Noordwijk CGE, WallisDeVries MF, Olff $H$. in press. Effects of large herbivores on grassland arthropod diversity. Biol Rev. doi:10.1111/brv.12113.

Veldhuis MP, Howison RA, Fokkema RW, Tielens E, Olff H. 2014. A novel mechanism for grazing lawn formation: large herbivore-induced modification of the plant-soil water balance. J Ecol 102:1506-17.

Weigmann G. 2006. Hornmilben (Oribatida): Acari, Actinochaetida. Keltern: Goecke \& Evers. 